\title{
Institutional Reform Litigation: Representation in the Remedial Process
}

Federal courts today systematically reform institutions ${ }^{1}$ in both the public and private sectors to redress unlawful employment discrimination, ${ }^{2}$ to improve prison conditions, ${ }^{3}$ to desegregate public schools, ${ }^{4}$ to reapportion electoral districts, ${ }^{5}$ and to remedy a host of other institutional wrongs. ${ }^{6}$ Because institutional structures and practices are complex, the formulation of a remedy in a lawsuit seeking institutional reform often affects many individuals and groups who are not among the original parties to the suit and whose interests are not represented in the remedial process by one of the original parties. Those persons and groups are frequently in a position to provide the court with information critical to the formulation of an effective decree and, if they are dissatisfied with the decree, to frustrate its implementation. They should therefore be made parties to the remedial

1. Institutions whose practices and structures courts are commonly asked to reform, such as business organizations, prisons, public schools, and various governmental entities and agencies, share several characteristics. They each exist to promote an organizational goal, see K. AZUMI \& J. HAGE, ORGANIZATIONAL SYSTEMS 7 (1972) (defining characteristic is existence of organizational goal), are the locus of the interaction of various persons, and possess an identifiable organizational structure, see Scott, Organization Theory: An Overview and an Appraisal, in ORGANIZATIONAL SYSTEMS: GENERAL SYSTEMS APPROACHES TO COMPLEX ORGANIZATIONS 99-100 (F. Baker ed. 1973) (defining characteristic is system of structural interpersonal relations). But $c f$. J. MARCH \& H. SIMON, ORGANIZATIONS 1 (1958) (any definition is less than fully adequate because organizations exist as empirical phenomonena that cannot be fitted into simple classifications).

2. See Civil Rights Act of 1964, Title VII, $\S \S 701-716,42$ U.S.C. $\S \S 2000 \mathrm{e}$ to $2000 \mathrm{e}-17$ (1976) (rendering unlawful employment practices that discriminate on basis of race, color, religion, sex, or national origin). The courts have remedied unlawful employment discrimination in both the public and private sectors. See, e.g., Franks v. Bowman Transp. Co., 424 U.S. 747 (1976) (private sector); Albemarle Paper Co. v. Moody, 422 U.S. 405 (1975) (private sector); Kirkland v. New York State Dep't of Correctional Servs., 520 F.2d 420 (2d Cir. 1975) (public sector), cert. denied, 429 U.S. 823 (1976).

3. See, e.g., Hutto v. Finney, 437 U.S. 678, 685-88 (1978) (prison conditions found to constitute cruel and unusual punishment); Gates v. Collier, 501 F.2d 1291, 1299-1322 (5th Cir. 1974) (same).

4. See, e.g., Columbus Bd. of Educ. v. Penick, 443 U.S. 449, 465-68 (1979) (systemwide school desegregation appropriate relief for systemwide violation); Swann v. Charlotte-Mecklenburg Bd. of Educ., 402 U.S. 1, 22-31 (1971) (busing of school children appropriate component of remedy to school segregation); Brown v. Board of Educ., 347 U.S. 483 (1954) (Brown I) (segregated public schools are unconstitutional), supplemented, 349 U.S. 294 (1955) (Brown II) (implementation order).

5. See, e.g., Connor v. Finch, 431 U.S. 407, 419-20 (1977) (court possesses broad powers to reapportion state legislative districts to satisfy one man, one vote requirement); Reynolds v. Sims, 377 U.S. 533, 568 (1964) (seats in state legislature must be apportioned based on population); Baker v. Carr, 369 U.S. 186, 208-37 (1962) (adequacy of legislative apportionment is justiciable issue).

6. Several authors have discussed the emergence of institutional reform litigation and have identified many of its unique procedural needs. See, e.g., Chayes, The Role of the Judge in Public Law Litigation, 89 HARV. L. REV. 1281, 1284 (1976) (unlike traditional lawsuits involving disputes between private parties about private rights, institutional reform lawsuits attempt to vindicate constitutional or statutory policies and consequently have unique procedural needs); Fiss, The Supreme Court 1978 Term Foreword: The Forms of Justice, 93 HARv. L. REV. 1, 2, 35-36 (1979) (bureaucratic nature of institutions whose practices such suits seek to alter gives rise to peculiar procedural needs). 
process. This Note proposes that Rules $19^{7}$ and $24^{8}$ of the Federal Rules of Civil Procedure be amended to create mechanisms through which such persons can routinely be joined and allowed to intervene in the remedial phase of institutional litigation.

\section{The Remedial Stage of Institutional Litigation}

Courts fashion institutional remedies most effectively when all persons who may be affected by those remedies participate as parties in the remedial process. Nevertheless, the Federal Rules of Civil Procedure do not provide for those persons' joinder or intervention.

\section{A. Institutional Remedies}

The task of formulating and implementing a remedy in traditional litigation involves little complexity. A court ordinarily makes an injured plaintiff whole by awarding him damages or by ordering the defendant specifically to perform his obligations. ${ }^{9}$ The direct burden of each of those remedies falls on the person or persons who injured the plaintiff. ${ }^{10}$ Fur-

7. FED. R. CIV. P. 19. This rule provides in relevant part for the joinder of persons who are necessary to the resolution of a lawsuit. A person who is subject to service of process and whose joinder will not deprive the court of jurisdiction over the subject matter of the action is required to be joined if in his absence complete relief cannot be accorded among those already parties, or if he claims an interest in the subject matter of the action and is so situated that the disposition of the action in his absence may practically impair his ability to protect that interest or expose one of the parties to a risk of double or inconsistent obligations. Id. See generally Hazard, Indispensable Party: The Historical Origin of a Procedural Phantom, 61 CoLUM. L. REV. 1254, 1256-62 (1961) (tracing evolution of necessary parties doctrine from era of Lord Nottingham, Lord Chancellor of England from 1673 to 1682); Reed, Compulsory Joinder of Parties in Civil Actions (pts. 1-2), 55 MICH. L. REV. 327, 483 (1957) (discussing modern evolution of necessary parties doctrine); Note, The Distorted Adversarial Posture of Title VII Affirmative Action Challenges, 128 U. PA. L. REV. 1543 (1980) (proposing expansive application of Rule 19 in suits challenging affirmative action).

8. FED. R. GIV. P. 24. This Rule provides in relevant part for the intervention of right of a person who claims an interest in the transaction that is the subject of the action and who is so situated that disposition of the action in his absence may practically impair his ability to protect that interest, unless his interest is adequately represented by an existing party. The Rule provides for permissive intervention of a person with a claim or defense that has a question of fact or law in common with the main action. Id. See generally Jones, Litigation Without Representation: The Need for Intervention to Affirm Affirmative Action, 14 HARV. C.R.-C.L. L. REV. 31 (1979) (discussing need for expanded intervention in suits challenging affirmative action); Shapiro, Some Thoughts on Intervention Before Courts, Agencies, and Arbitrators, 81 HARV. L. REV. 721 (1968) (identifying factors that should inform decision to let applicant intervene in suit that may affect his interests); Yeazell, Commentary-Intervention and the Idea of Litigation: A Commentary on the Los Angeles School Case, 25 U.C.L.A. L. REV. 244 (1977) (discussing one case in which state court allowed intervention of white parents in remedial phase of school desegregation suit).

9. When fashioning relief, a court ordinarily chooses from a narrow range of remedial options the one that will most effectively remedy the plaintiff's injury. See Chayes, supra note 6, at 1282-83 ("IT]he scope of the relief [in traditional litigation] is derived more or less logically from the substantive violation under the general theory that the plaintiff will get compensation measured by the harm caused by the defendant's breach of duty-in contract by giving plaintiff the money he would have had absent the breach; in tort by paying the value of the damage caused.")

10. Plaintiffs in traditional litigation often assert claims against more than one defendant. When 
thermore, in most cases an extensive body of law guides the court's selection of a remedy and constrains its freedom to consider the indirect effects potential remedies are likely to have on persons other than the parties. ${ }^{11}$ There is therefore no reason for such persons to participate in the remedial process.

Institutional reform litigation differs markedly from this paradigm. Once a court determines that plaintiffs are entitled to institutional reform, it must fashion an ad hoc remedy ${ }^{12}$ that will effectively prevent future injury to the plaintiff class and eliminate the current effects on that class of the institution's illegal past practices. ${ }^{13}$ The selection and implementation of such an ad hoc remedy may affect a variety of people who depend on the defendant institution for benefits, including its employees, investors, customers, and other beneficiaries. ${ }^{14}$

they do so, however, remedial burdens are imposed only on those defendants who are found to have breached a duty to the plaintiff. See W. PROSSER, THE LAW OF TORTS § 52, at 313-14 (4th ed. 1971) (only where "rough practical apportionment" of damages among defendants is not possible may each defendant who has been cause of some damage suffered by plaintiff be held liable for entire loss).

11. In contract law, for example, a court is required to remedy a breach by awarding damages "if damages would be adequate to protect the expectation interest of the injured party." RESTATEMENT (SECOND) OF CONTRACTS $\S 359(1)$ (1979). In determining the adequacy of damages, a court is directed to look to the likelihood that damages could be collected and the difficulty of proving damages and procuring a suitable substitute for performance. Id. $\S 360$. Only if the adequacy of damages is uncertain can the court proceed to consider such additional factors as the ambiguity of the terms of the contract, id. $\$ 362$, the lack of security for performance, $i d$. $\$ 363$, the likelihood that specific enforcement would impose on the court burdens in enforcement or supervision that are disproportionate to the advantages gained from enforcement, id. $\S 366$, and the likelihood that specific performance would cause unreasonable hardship or loss to the party in breach or to third persons, id. $\S 364$. See id. $\S 359$ comment a.

12. See Albemarle Paper Co. v. Moody, 422 U.S. 405, 416 (1975) (Title VII "implicitly recognizes that there may be cases calling for one remedy but not another . . . these choices are, of course, left in the first instance to the district courts"); Brown v. Board of Educ., 349 U.S. 294, 300 (1955) (Brown II) (remedy formulation in school desegregation cases requires practical flexibility and facility for adjusting and reconciling public and private needs in light of particular circumstances of each school district).

13. See, e.g., Albemarle Paper Co. v. Moody, 422 U.S. 405, 418 (1975) (in Title VII suit, district court decree must "so far as possible eliminate the discriminatory effects of the past as well as bar like discrimination in the future”); Green v. County School Bd., 391 U.S. 430, 438 n.4 (1968) (applying same standard to constitutional violations).

14. Institutional reform litigation may affect prospective employees, see, e.g., Rios v. Enterprise Ass'n Steamfitters Local 638, 501 F.2d 622, 629-32 (2d Cir. 1974) (prospective job applicants burdened by remedial hiring quota imposed in Title VII suit), current employees, see, e.g., Franks v. Bowman Transp. Co., 424 U.S. 747, 778 (1976) (current employees burdened in Title VII suit by award of competitive seniority rights that determine preferential treatment at expense of other employees); Gates v. Collier, 501 F.2d 1291, 1305-08 (5th Gir. 1974) (prison guards' authority to discipline prisoners reduced), owners, see, e.g., Marcus v. Putnam, 60 F.R.D. 441, 443 (D. Mass. 1973) (certain shareholders allegedly burdened by consent decree that settled litigation against corporation), customers, see, e.g., Cascade Natural Gas Corp. v. El Paso Natural Gas Co., 386 U.S. 129, 135-36 (1967) (industrial purchaser of defendant's product affected by antitrust litigation that threatened defendant's ability to market product at competitive rates); Environmental Defense Fund, Inc. v. Ruckelshaus, 439 F.2d 584 (D.C. Cir. 1971) (users of DDT affected by litigation seeking to ban its use), and beneficiaries of the institution's mission, see, c.g., United States v. Perry County Bd. of Educ., 567 F.2d 277, 279-80 (5th Gir. 1978) (white children, parents, and teachers affected by school desegregation); Dodson v. Salvitti, 77 F.R.D. 674, 677 (E.D. Pa. 1977) (residents of area designated 
Remedies are selected through an adversary process in which each party presents to the court the arguments and evidence best calculated to protect its interests. ${ }^{15}$ The parties do not routinely present arguments and evidence that reveal the disadvantages of remedies that impose burdens on persons who may be affected by the decree but who are not themselves parties. ${ }^{16}$ Unless such persons are allowed to represent themselves in the remedial process, a court may impose an excessive proportion of the remedial burden on them. Perhaps more importantly, lacking the information those persons could contribute, a court may choose a remedy that ameliorates the plaintiffs' injury less fully and efficiently than would other remedial alternatives. ${ }^{17} \mathrm{~A}$ court, having chosen a remedy ill-adapted to the unique needs of an institution, may then need to supplement its decree until an effective remedy is discovered through trial and error. ${ }^{18}$ This

by court as site of remedial housing project affected by suit reforming practices of public housing authority).

15. See O. FISs, THE CIVIL RIGHTS INJUNCTION 30 (1978) (remedy formulation is "structured on the contest model" of two parties vying against one another, with the judge as an impartial umpire); Note, "Mastering" Intervention in Prisons, 88 YALE L.J. 1062, 1077-78 (1979) ("TT]he opposing sides perceive themselves as competing for a favorable decision.") The process remains adversarial regardless of the procedure the court uses to formulate the remedy. See Special Project, The Remedial Process In Institutional Reform Litigation, 78 CoLUM. L. REV. 784, 796-812 (1978) (identifying five such procedures: remedial abstention, court imposition of remedy, court selection of remedy, mastersupervised remedy formulation, and negotiation of remedy).

16. A court frequently must decide which of several groups must bear the burden of remedying plaintiffs' injury. In school desegregation litigation, for example, a court must decide how much of the remedial burden it will place on the district's taxpayers by ordering the expenditure of monies to upgrade facilities and bus students, on students from each of the areas within the district by ordering them to be bused lengthy distances or to schools with facilities inferior to those of the schools they previously attended, and on faculty and potential faculty by ordering faculty reassignments or imposing hiring objectives. The school district's legal representatives can be expected to identify the disadvantages of any component of a remedial plan only when that component is less burdensome to those who control the school district than the available alternatives. If plaintiffs are represented by professional group rights litigators, plaintiffs' counsel may fail to identify the disadvantages of certain remedial components because to do so would undermine counsel's litigation objectives. See Special Project, supra note 15 , at 879 . Plaintiffs may also fail to identify fully the hardships created by a potential remedy because they have less incentive to be concerned with those hardships than do the people who would bear them. In addition, the parties may choose not to bring the interests of non-parties to the court's attention because the parties prefer not to dilute their control over remedy formulation or desire to minimize litigation costs. See id. at $\mathbf{8 7 9 - 8 0}$.

17. Potentially affected non-parties are often aware of unique characteristics of the institution that may impede the implementation of certain remedies, see Note, Implementation Problems in Institutional Reform Litigation, 91 HARV. L. REV. 428, 440 (1977), including the means through which they and other persons who interact with the institution may interfere with the implementation of certain remedies. Id. (discussing Mills v. Board of Educ., 348 F. Supp. 866 (D.D.C. 1972), in which teachers and school principals delayed implementation of due process standards relating to student discipline). See Baker v. Clement, 247 F. Supp. 886, 896-97 (M.D. Tenn. 1965) (intervenors successfully challenged defendant's proposed remedial plan, to which plaintiff had acceded). The court's eventual remedy in the Baker litigation was based on the intervenors' proposals. Compare Baker v. Ellington, 273 F. Supp. 174, 176-77 (M.D. Tenn. 1967) (remedy ultimately adopted) with Baker v. Clement, 247 F. Supp. at 890 n.3 (remedy proposed by intervenors).

18. A court is under a duty to render an effective remedy in an institutional reform case. Green v. County School Bd., 391 U.S. 430,438 n.4 (1968). It may therefore need to revise a defective remedy when "a better appreciation of the facts in light of experience indicates that the decree is not properly 
wastes judicial resources and denies plaintiffs the immediate relief to which they are entitled.

A court can also implement the remedy it chooses with more efficiency if all persons affected by the remedy are party to its selection. Persons adversely affected by a remedial decree are likely to desire to protect their interests and may therefore seek to avoid the decree's effects through extrajudicial means. ${ }^{19}$ They may disrupt a remedial order by violating its terms ${ }^{20}$ or by taking action that, although not proscribed, is inconsistent with the remedial regime contemplated by the court. ${ }^{21}$ If such persons are parties to the litigation, a court can force them to cooperate in the remedy's implementation by issuing orders directing them to comply with its terms and by imposing sanctions on them if they refuse to do so. If they are not parties, however, the court cannot easily issue such orders or impose such sanctions because non-parties are not bound by the suit's resolu-

adapted to accomplishing its purposes." King-Seeley Thermos Co. v. Aladdin Indus., 418 F.2d 31, 35 (2d Cir. 1969).

19. If such persons are not made parties to the litigation, they may also seek to avoid the decree's effects through collateral judicial proceedings. Non-parties cannot be bound by the res judicata and collateral estoppel effects of a judgment unless they are in privity with a party to the suit. See Consumers Union, Inc. v. Consumer Prod. Safety Comm'n, 590 F.2d 1209, 1221 (D.C. Cir. 1978), rev'd on other grounds sub nom. GTE Sylvania, Inc. v. Consumers Union, Inc., 445 U.S. 375 (1980) ("[A] judgment cannot bind those who were not before the court either in person or through some sort of representative.") Privity exists only if the interest of the person who is not a party is represented by another who has been authorized to act as a party on his behalf or if the substantive legal right of the person who is not a party stands or falls according to a judgment involving another who is a party to the lawsuit. F. JAMES \& G. HAZARD, Civil PROCEDURE 575-76 (2d ed. 1977).

For an instance in which an affected person achieved collateral relief, see Harmon v. San Diego County, 477 F. Supp. 1084 (S.D. Cal. 1979). In that case, the county had successfully opposed plaintiff's motion to intervene in an earlier suit that had resulted in a consent decree, pursuant to which the county agreed "not [to] discriminate on the basis of race, sex, or national origin in hiring . . . ." Id. at 1090. Acting in reliance on this decree, the county refused to hire plaintiff for a position for which the county conceded he was the best qualified applicant. The court held that no party to the earlier litigation had represented plaintiff's interest therein and that he was therefore not bound by the decree entered in that litigation. Thus, the county could not assert its reliance on that decree as a valid defense in plaintiff's current Title VII action. Id. at 1091-92.

20. See, e.g., United States v. Hall, 472 F.2d 261, 263-64 (5th Cir. 1972) (black activist interfered with school desegregation order); Morgan v. Kerrigan, 401 F. Supp. 216, 224-25 (D. Mass. 1975), aff'd, 530 F.2d 401 (1st Cir.), cert. denied, 426 U.S. 935 (1976) (white students and parents violently disrupted school desegregation plan).

21. The effectiveness of an institutional decree often depends on the voluntary cooperation of persons affected by the decree. For example, the parents of white children may frustrate a school desegregation order by withdrawing their children from the public school system or by moving, see Coleman, New Incentives for Desegregation, 7 HUMAN RIGHTS 10, 13 (1978), white residents of a neighborhood may frustrate the purpose of the construction of integrated public housing by fleeing the neighborhood, see Otero v. New York City Hous. Auth., 484 F.2d 1122, 1135-37 (2d Cir. 1973) (discussing "tipping point" phenomenon), or prison guards may frustrate the implementation of prison reform by adopting informal procedures that reward those prisoners who cooperate in their subversion of other prisoners' rights, see Sturm, The Rhode Island Prison Decree, in D. LOUISELL \& G. Hazard, Cases and Materials on Pleading and Procedure STATe and Federal 114 (4th ed. 1979) (citing recalcitrance of prison guards as one of factors that rendered ineffective court-ordered reform of Rhode Island prison system). 
tion. ${ }^{22}$ Instead, the court must either try to influence their behavior through orders against the parties ${ }^{23}$ or join them as parties and allow them to participate in the formulation of supplemental orders. ${ }^{24}$ Facing

22. A court order "is binding only upon the parties to the action, their officers, agents, servants, employees, and attorneys, and upon those persons in active concert or participation with them who receive actual notice of the order by personal service or otherwise." FED. R. CIV. P. 65(d). See Alemite Mfg. v. Staff, 42 F.2d 832, 833 (2d Cir. 1930) (injunction validly runs against person not party to lawsuit only insofar as he is legally identified with enjoined party or is prevented from abetting enjoined party's violation of injunction). Similarly, a court can institute contempt proceedings only against a person bound by an injunction.

[O]nly those acting in concert with, or aiding or abetting, a party can be held in contempt for violating a court order. One whose interest is independent of that of a party and who is not availed of as a mere device for circumventing a decree is not subject to such sanctions . . . . The law exposes to summary punishment only those who have already had their rights adjudicated in court.

Wright v. County School Bd., 309 F. Supp. 671, 677 (E.D. Va. 1970), rev'd sub nom. Wright v. Council of Emporia, 442 F.2d 570 (4th Cir. 1971), rev'd, 407 U.S. 451 (1972). Accord Backo v. Local 281, 438 F.2d 176, 180-81 (2d Cir. 1970) (individual officers of union who were legally identified with union that was subject to decree abetted violation of order and were subject to contempt), cert. denied, 404 U.S. 858 (1971); NLRB v. Sequoia Dist. Council of Carpenters, 568 F.2d 628, 633-34 (9th Cir. 1977) (same); Alemite Mfg. v. Staff, 42 F.2d 832, 833 (2d Cir. 1930) ("[T]he only occasion when a person not a party may be punished [for violating an injunction], is when he has ... abet[ted] the defendant, or . . . [is] . . . legally identified with him.")

Because persons who may be affected by the choice of an institutional remedy are usually not legally identified with the institutional defendant and are able to frustrate the implementation of a remedy through action independent of the institution's actions, they cannot be bound by a decree or held in contempt for its violation unless they are made parties to its formulation. The principal exception to this rule is the case of employees affected by a judgment against their employer. Even they, however, cannot be bound in instances in which their legal rights are not derivative of those of their employer, as, for example, in the case of employment discrimination litigation. Moreover, employees who will be bound by a decree against their employer should be made parties because "it is middlelevel professional and managerial staff and lower-level operational staff who will be the actual implementers of change." Note, supra note 17 , at 440 . Such persons are especially likely to possess information necessary to the shaping of an effective decree. Id.

23. In Valley v. Rapides Parish School Bd., 646 F.2d 925, modified, 653 F.2d 941 (5th Gir. 1981), cert. denied, 102 S. Ct. 1430 (1982), for example, three white families attempted to avoid a school desegregation decree by obtaining a state court order transferring custody of their daughters to persons living in a part of the school district from which the girls would attend an all-white school. The district judge, recognizing that the girls were not bound by its decree, coerced their compliance by joining the state court judge to the litigation and enjoining him from interfering with the district court's orders and from enforcing any of his own orders. The district judge also ordered school officials, over whom he had jurisdiction, to withold credit for the semester the girls attended the all-white school if the girls chose to attend an all-white private academy instead of the integrated public school to which they had been assigned. See id. at 934-36. The girls were therefore left with the option of attending the integrated public school or repeating the semester for which their credit was denied. The court of appeals ultimately concluded that the district court was without power to withold the girls' academic credit if they chose to attend a private school. Id. at 944.

24. A court can make persons who were not bound by the original decree parties to a supplemental order that restricts their ability to frustrate the decree. See, e.g., United States v. Hall, 472 F.2d 261, 268 (5th Cir. 1972) (private citizen ordered not to interfere with desegregation of schools); Faubus v. United States, 254 F.2d 797 (5th Cir.) (state governor ordered not to interfere in desegregation of Little Rock public schools), cert. denied, 358 U.S. 829 (1958); Kasper v. Brittain, 245 F.2d 92, 94 (6th Cir. 1957) (private citizen ordered not to make inflamatory speeches against school desegregation), cert. denied, 335 U.S. 834 (1957). Such orders, however, like an original remedial decree, cannot bind the affected persons unless those persons are given the opportunity to participate as parties in the formation of the supplemental order or the order is in the nature of a temporary restraining order. See O. Fiss, INJUNCTIONS 628-29 (1972); United States v. Hall, supra, 472 F.2d at 267. 
this prospect, a court should join them at a time when it can impress them with its good faith concern for their interests and when they can meaningfully contribute to the remedy's formulation. ${ }^{25}$

\section{B. The Nonrepresentation of Affected Interests}

Although individuals and groups who may be affected by the choice of a remedy should participate in its formulation, the current provisions of the Federal Rules of Civil Procedure for intervention ${ }^{26}$ and joinder ${ }^{27}$ do not provide a mechanism through which they may be made parties to the litigation..$^{28}$ Attempts to allow such persons to participate informally cannot adequately address the courts' needs.

\section{Intervention Under Rule 24}

Rule 24 authorizes certain persons, whose interests may diverge from those of the parties, to intervene in a lawsuit either as of right ${ }^{29}$ or permissively. ${ }^{30} \mathrm{~A}$ few courts have interpreted this rule to allow intervention in institutional reform litigation by persons who may be affected by the selection of a remedy. ${ }^{31}$ This practice, however, has not been common, ${ }^{32}$ in

\section{Any other procedure}

will tend to reduce the district courts to issuers of "'paper' decrees which neither adjudicate nor, in $\backslash$ the end, protect rights." This is hardly a sound way to expend the energies of overburdened district judges. Furthermore, plaintiffs will be frustrated by their failure to obtain effective relief ... after lengthy litigation and the attendant inconvenience and expense.

Carpenters 46 N. Cal. Counties Joint Apprenticeship \& Training Comm. v. Eldredge, 51 U.S.L.W. 3282,3283 (October 6, 1982) (Rehnquist, J., dissenting from denial of cert.) (concluding that employers who hire employees from pool of applicants referred by union are necessary parties in Title Vil suit against union because relief against union alone would not prevent employers from continuing to discriminate among applicants).

26. FED. R. CIV. P. 24. See supra note 8.

27. FED. R. CIV. P. 19. See supra note 7 .

28. Rule 23, which provides for the maintenance of class actions, cannot be used to join persons who may be affected by the choice of a remedy but who are not parties to the litigation. This Rule may be employed to certify a class and to ensure its adequate representation only after a class representative has been made a party to the litigation. See English v. Seaboard Coast Line R.R., 465 F.2d 43, 48 (5th Cir. 1972) (joinder of class effected in two steps: 1) joinder of representative of class under Rule 19 as necessary party; 2) certification of class and its representative under Rule 23). Cr. Pan Am. World Airways v. United States Dist. Court, 523 F.2d 1073, 1079 (9th Cir. 1975) ("[N]otice for the purpose of bringing the claims of unnamed members of the plaintiff class before the court may not issue before a class action has been certified.")

29. Intervention of right is available to a person who claims an interest relating to the subject matter of a suit and who is so situated that the disposition of the suit in his absence may practically impair his ability to protect that interest, unless his interest is adequately represented by a party. FED. R. CIV. P. 24(a).

30. Permissive intervention is available to a person at the discretion of the court if he has a claim or defense that raises a question of law or fact in common with the main action. FED. R. GIV. P. 24(b).

31. Some courts have allowed such intervention as of right. See, e.g., Cascade Natural Gas Corp. v. El Paso Natural Gas Co., 386 U.S. 129, 135-36 (1967) (intervention of right allowed in remedial stage of antitrust suit by industrial purchaser of defendant's product who had interest in maintaining competitive market); Johnson v. San Francisco Unified School Dist., 500 F.2d 349, 352-54 (9th Cir. 
part because the substantive law affords those persons no protection from the adverse effects of institutional remedies. ${ }^{33}$

Furthermore, persons with an interest in the choice of a remedy often fail to attempt to intervene. Some are unaware that their interests are threatened by litigation in which they are not represented. Others conclude that their participation would have little effect on the ultimate decision and, for that reason, choose to protect their interests in another fo-

1974) (intervention of right allowed in remedial stage of school desegregation suit by parents of children of Chinese ancestry); Smuck v. Hobson, 408 F.2d 175, 178-82 (D.C. Cir. 1969) (intervention of right allowed after judgment in school desegregation suit by parents of white children to enable them to appeal remedial decree school board chose not to appeal).

Other courts have done so permissively. See, e.g., United States v. Local 638, Enterprise Ass'n Steamfitters, 347 F. Supp. 164, 166 (S.D.N.Y. 1972) (City of New York permitted to intervene in Title VII suit against union where City had direct financial interest in decree and where City's plan to increase minority representation in construction trade might be affected by resolution of case); Williams v. Kimbrough, 295 F. Supp. 578, 580-81 (W.D. La. 1969) (black former elementary school teachers permitted to intervene in school desegregation case).

32. Many courts have denied persons affected by the selection of a remedy the opportunity to intervene of right. See, e.g., United States v. Perry County Bd. of Educ., 567 F.2d 277, 279 (5th Gir. 1978) ("TT]here are innumerable instances in which children, parents, and teachers may be deprived of various 'rights' (e.g., the 'right' to attend a neighborhood school) without having had the opportunity to participate directly in the judicial proceedings which divest them of those "rights." "); Rios v. Enterprise Ass'n Steamfitters Local 638, 520 F.2d 352, 357 (2d Cir. 1975) (white job applicants not allowed to intervene in Title VII suit); Horton v. Lawrence County Bd. of Educ., 425 F.2d 735, 73536 (5th Cir. 1970) (per curiam) (representatives of black teachers not allowed to intervene in remedial phase of school desegregation suit to protect interest of such teachers); Butterworth v. Dempsey, 229 F. Supp. 754, 798-99 (D. Conn.) (municipalities adversely affected by reapportionment decree not allowed to intervene in legislative reapportionment suit), aff'd sub nom. Town of Franklin v. Butterworth, 378 U.S. 562 (1964) (per curiam).

Many courts have also denied such persons the opportunity to intervene permissively. See, e.g., United States v. Perry County Bd. of Educ., 567 F.2d 277, 280 (5th Cir. 1978) (parents of white children denied permission to intervene in school desegregation case); Horton v. Lawrence County Bd. of Educ., 425 F.2d 735, 736 (5th Cir. 1970) (per curiam) (representative of black teachers denied permission to intervene in school desegregation case); United States v. Carrols Dev. Corp., 454 F. Supp. 1215, 1221 (N.D.N.Y. 1978) (defendant's lessor denied permission to intervene in antitrust action where provisions of proposed remedy might adversely affect lessor's rights under lease); Marcus v. Putnam, 60 F.R.D. 441,443 (D. Mass. 1973) (shareholders of mutual fund denied permission to intervene to challenge consent decree in derivative action).

33. Some courts have denied persons affected by the choice of a remedy the opportunity to intervene because their interest is not "direct, substantial, and legally protectable." Diaz v. Southern Drilling Corp., 427 F.2d 1118, 1124 (5th Cir.) (quoting Hobson v. Hansen, 44 F.R.D. 18, 24-27 (D.D.C. 1968), rev'd in part sub nom. Smuck v. Hobson, 408 F.2d 175 (D.C. Cir. 1969)), cert. denied, 400 U.S. 878 (1970). See Dodson v. Salvitti, 77 F.R.D. 674, 677 (E.D. Pa. 1977) (residents of area designated by court to be site of remedial housing project lacked protectable interest sufficient to permit intervention). But see Blake v. Pallan, 554 F.2d 947, 952 (9th Cir. 1977) ("[S]everal courts, including this one, have, implicitly at least, rejected the notion that Rule 24(a)(2) requires 'a specific legal or equitable interest." ") Other courts have denied intervention for different reasons. See East Powelton Concerned Residents v. United States Dep't of Health \& Urban Dev., 69 F.R.D. 392, 39293 (E.D. Pa. 1975) (developer of urban renewal project denied permission to intervene because he asserted no claims raising common legal or factual issues with those raised in suit to set aside urban renewal plan although court recognized that its decision might affect developer's project). Some courts have refused permission to intervene without giving any reasons. See United States v. Perry County Bd. of Educ., 567 F.2d 277, 280 (5th Cir. 1978) (parents of white children denied permission to intervene in school desegregation suit in one sentence order without evidentiary hearing or findings of fact). 
rum $^{34}$ or not to protect them at-all. In addition, groups that could litigate as classes ${ }^{35}$ often fail to intervene because no member has a personal interest sufficiently large for him to come forward on the group's behalf. ${ }^{36}$

\section{Joinder of Non-Parties Under Rule 19}

Affected persons who are not allowed or do not attempt to intervene at the remedial stage of a lawsuit are rarely joined pursuant to Rule 19 in part because their interests in the litigation are not "legally protectable"37 and in part because courts have resisted the conclusion that the parties cannot obtain complete relief unless such persons are joined. ${ }^{38}$ Courts have

34. Some potentially affected persons may desire to initiate a collateral judicial proceeding. In GTE Sylvania, Inc. v. Consumer Prod. Safety Comm'n, 598 F.2d 790 (3d Cir. 1979), affd, 447 U.S. 102 (1980), for example, Consumers Union had requested certain documents from the Consumer Products Safety Commission. The Commission agreed to release the documents, prompting the corporations that had submitted the documents to commence litigation in the district of Delaware to block their release. Consumers Union was not made a party to that suit, nor did it attempt to intervene, choosing instead to initiate a separate suit in the District of Columbia, joining all of the plaintiffs in the Delaware action and the Commission as defendants. Id. at 796.

Other potentially affected persons may prefer to protect their interests through extrajudicial means. See, e.g., Morgan v. Kerrigan, 401 F. Supp. 216, 225 (D. Mass. 1975) (members of white community actively resisted school desegregation order), aff', 530 F.2d 401 (1st Cir.), cert. denied, 426 U.S. 935 (1976).

35. A representative of a class may intervene pursuant to Rule 24 and seek certification to participate on the class' behalf pursuant to Rule 23. See United States v. Board of School Comm'rs, 466 F.2d 573, 576 (7th Cir. 1972) (intervention of two black students in school desegregation suit conditioned on determination that they are proper representatives of the class on whose behalf they seek to intervene), cert. denied, 410 U.S. 909 (1973).

36. This problem attends all litigation affecting classes of individuals. See Hawaii v. Standard Oil Co., 405 U.S. 251 (1972). The problem is exacerbated here by the timeliness requirement of Rule 24: a class can avoid the adverse effect of a remedy under consideration in a pending lawsuit only if a class member volunteers to represent the class in timely fashion. See Note, The Timeliness Threat to Intervention of Right, 89 YALE L. J. 586, 593 (1980) (timeliness is first requirement movant must satisfy to intervene suceessfully). Cr. Preston v. Thompson, 589 F.2d 300, 304 (7th Cir. 1978) (motion by prison guards to intervene in prison condition litigation filed three weeks after grant of preliminary relief denied as untimely).

37. Rule 19(a)(2) provides that a person-who is subject to service of process and whose joinder will not deprive the court of jurisdiction should be joined if he claims an interest relating to the subject matter of the litigation and is so situated that the disposition of the suit in his absence may practically impair his ability to protect that interest or expose one of the parties to a risk of double, multiple, or inconsistent obligations. FED. R. CIV. P. 19(a)(2). The courts have uniformly invoked Rule 19(a)(2) only where the "interest relating to the subject matter" of the litigation is an interest protectable under the applicable substantive law. See, e.g., Smith v. B \& O R.R., 473 F. Supp. 572, 583-84 (D. Md. 1979) (employees who benefited from allegedly discriminatory job assignment procedure are not necessary parties to suit seeking reform of procedure because they "would not be able to argue for the inequity of declaring invalid an unlawful agreement"); Spirt v. Teachers Ins. \& Annuity Ass'n, 416 F. Supp. 1019, 1022-23 (S.D.N.Y. 1976) (male participants in employer-funded pension plan not necessary parties in suit by female employees challenging validity of certain provisions of plan); Hoots v. Pennsylvania, 359 F. Supp. 807, 821-22 (W.D. Pa. 1973) (school districts with no legal right to retain their present boundaries are not necessary parties to suit brought to change the boundaries of a contiguous district), appeal dismissed, 495 F.2d 1095 (3d Cir.), cert. denied, 419 U.S. 884 (1974).

38. Rule 19(a)(1) provides that a person who is subject to service of process and whose joinder will not deprive the court of jurisdiction should be joined if in his absence complete relief cannot be accorded among those already parties. FED. R. GrV. P. 19(a)(1). A few courts have relied on this rule to join persons who may be affected by a remedy and against whom the court expects to issue an 
also sometimes concluded that Rule 19 is inapplicable to suits whose object is the vindication of public rights. ${ }^{39}$

\section{Informal Participation}

Judges and special masters ${ }^{40}$ are ordinarily able to identify with little difficulty the persons who should participate in the remedial process ${ }^{41}$ and

order. See Bradley v. Milliken, 484 F.2d 215, 251-52, 280 (6th Cir. 1973) (prior to implementing a metropolitan school busing plan, each affected district must first be made a party to the litigation and afforded an opportunity to be heard concerning remedy formulation but not the underlying liability of the central city school system), rev'd on other grounds, 418 U.S. 717 (1974); cf. Eldredge v. Carpenters 46 N. Cal. Counties Joint Apprenticeship \& Training Comm., 440 F. Supp. 506, 518-22 (N.D. Cal. 1977) (employers who hire employees from pool of applicants referred by union are necessary parties in Title VII suit against union because relief against union alone would not prevent cmployers from continuing to discriminate among referred applicants), rev'd, 662 F.2d 534 (9th Cir. 1981), cert. denied, 51 U.S.L.W. 3282 (October 6, 1982). Most courts, however, have resisted this view, concluding instead that they can select and implement an effective remedy without joining those who may be adversely affected by the decree. The court of appeals, for example, reversed the decision in Eldredge, supra, concluding that it would be proper for the district court to order a change in the union's referral practices without attempting to reduce the risk that the employers would respond to the injunction in ways that perpetuate discriminatory hiring. Eldredge v. Carpenters $46 \mathrm{~N}$. Cal. Counties Joint Apprenticeship \& Training Comm., 662 F.2d 534, 537 (9th Cir. 1981), cert. denied, 51 U.S.L.W. 3282 (October 6, 1982). See also Illinois ex rel. Scott v. Butterfield, 396 F. Supp. 632, 646 (N.D. Ill. 1975) (complete relief can be accorded in suit seeking to limit expansion of operations at city airport without participation of city); Hoots v. Pennsylvania, 359 F. Supp. 807, 821 (W.D. Pa. 1973) (complete relief can be accorded in suit brought to change boundaries of school district without participation of contiguous districts), appeal dismissed, 495 F.2d 1095 (3d Cir.), cert. denied, 419 U.S. 884 (1974).

39. See, e.g., National Licorice Co. v. NLRB, 309 U.S. 350, 363 (1940) (employees need not be joined in suit by NLRB to enjoin enforcement by employer of illegal labor contracts); Kirkland v. New York Dep't of Correctional Servs., 520 F.2d 420, 423-24 (2d Cir. 1975) (employees whose advancement opportunities may be threatened by resolution of suit claiming employment discrimination not necessary parties), cert. denied, 429 U.S. 823 (1976); cf. Natural Resources Defense Council v. Berklund, 458 F. Supp. 925, 933 (D.D.C. 1978) (applicants for coal leases not indispensable parties to suit under National Environmental Policy Act brought to enjoin Secretary of Interior from issuing such leases), aff', 609 F.2d 553 (D.C. Cir. 1979).

Courts have also frequently resolved institutional reform lawsuits without addressing the argument that potentially affected persons may be necessary parties. See, e.g., Local Union No. 35 v. Hartford, 625 F.2d 416 (2d Cir. 1980) (blacks not joined in challenge to affirmative action plan), cert. denied, 453 U.S. 917 (1981); Gates v. Collier, 501 F.2d 1291 (5th Cir. 1974) (prison guards not joined to suit ordering sweeping prison reform).

40. Courts are empowered to refer matters to special masters in cases presenting special complexity or other exceptional conditions. FED. R. CrV. P. 53(b). Courts have frequently found such conditions present in the remedial phase of institutional litigation. See, e.g., Connor v. Finch, 419 F. Supp. 1072,1073 (S.D. Miss. 1976) (legislative reapportionment), rev'd on other grounds, 431 U.S. 407 (1977); Morgan v. Kerrigan, 401 F. Supp. 216, 227 (D. Mass. 1975) (school desegregation), aff'd, 530 F.2d 401 (1st Cir.), cert. denied, 426 U.S. 935 (1976); Hamilton v. Landrieu, 351 F. Supp. 549, 550 (E.D. La. 1972) (prison conditions). But see Wyatt v. Stickney, 325 F. Supp. 781, 785 (M.D. Ala. 1971) (refusing request to appoint master in suit remedying inadequate conditions in mental hospital).

Like judges, special masters acquire their knowledge about the defendant institution through formal and informal means. See, e.g., Hart v. Community School Bd., 383 F. Supp. 699, 767 (E.D.N.Y.) (master ordered to receive and report evidence and "to consult informally with the parties and with outside experts and others"), appeal dismissed, 497 F.2d 1027 (2d Cir. 1974), affd, 512 F.2d 37 (2d Cir. 1975).

41. See Chayes, supra note 6, at 1312 (judge's experiences on bench, relatively defined focus of public law litigation, and local setting of many institutions enable court to identify such persons). 
sometimes invite those persons to participate informally. Unless the informal participants are given the procedural rights of parties, however, including the opportunity to call and examine witnesses, to cross-examine witnesses presented by the parties, to propose remedial alternatives, and to discover evidence relevant to the selection of a remedy that no party wants to introduce, this practice cannot fully satisfy the court's informational needs ${ }^{42}$ or improve the court's ability to respond to attempts to frustrate the implementation of its remedial decree. ${ }^{43}$

\section{Amending the Rules: Standards for Remedial Joinder and Intervention}

In view of the inadequacy of other means of representation in the remedial process, the Federal Rules of Civil Procedure should be amended to authorize the joinder and intervention of some persons who may be affected by the remedy. ${ }^{44}$ The proposed amendment should establish alternative requirements for joinder or intervention of right at the remedial

42. Instead of giving non-parties these valuable procedural rights, judges and masters sometimes attempt to satisfy the court's informational needs by interrogating the parties' and the court's own witnesses and by meeting informally with interested non-parties. See, e.g., Amos v. Board of School Directors, 408 F. Supp. 765, 823 (E.D. Wis.), affd sub nom. Armstrong v. Brennan, 539 F.2d 625 (7th Cir. 1976), vacated per curiam on other grounds, 433 U.S. 672 (1977); Hart v. Community School Bd., 383 F. Supp. 699, 767-68 (E.D.N.Y.) appeal dismissed, 497 F.2d 1027 (2d Cir. 1974), affd, 512 F.2d 37 (2d Cir. 1975).

Judges and masters should not substitute their own witness examinations for examinations by interested non-parties. Unlike judges and masters, such non-parties often have a unique knowledge of the defendant institution, which they can bring to bear in examining witnesses. See Note, supra note 17, at 440 . Furthermore, a judge or master can effectively interrogate a witness only if the judge or master has formulated tentative hypotheses about the proper choice of a remedy. See Damaska, Presentation of Evidence and Factfinding Precision, 123 U. PA. L. REV. 1083, 1092 (1975); Frankel, The Search for Truth: An Umpireal View, 123 U. PA. L. REV. 1031, 1042 (1975). Having formulated such hypotheses, he is likely to question a witness only about the various remedial regimes that he has hypothesized and may fail to inquire about matters that he has not anticipated. He may also discount information that tends to disprove his hypotheses. See Damaska, supra, at 1092 (judge may "be more receptive to information conforming to his hypotheses than to that which clashes with them").

Because of their unique perspective on the defendant institution, informal participants may also be in the best position to propose an effective and efficient remedy. Cf. supra note 17 (courts have sometimes implemented remedial plans proposed by intervenors). They should therefore be given the opportunity to propose remedial alternatives. Finally, as an adjunct to the right to examine witnesses and propose remedial alternatives, informal participants should be given the opportunity to discover information relevant to the selection of a remedy that the parties wish to suppress, see supra p. 1477 \& n.16; otherwise their ability to contribute to the litigation will be limited by the extent of their personal knowledge.

43. A court cannot bind affected persons to its decree unless it makes them parties to the litigation. See supra notes 19 \& 22. Persons who participate in a litigation on an informal basis and without any procedural rights are therefore not bound by the res judicata and collateral estoppel effects of the court's order, see supra note 19 , and cannot be subjected to summary contempt proceedings, see supra note 22.

44. Persons who may be affected by the choice of a remedy but who lack an interest that is legally protectable are not and should not be joined or allowed to intervene prior to the determination of plaintiffs' right to relief. See supra pp. 1480-83 (discussing the application of current Rules 19 and 24 to such persons). 
phase of a lawsuit: ${ }^{45}$ a person should be made a remedial party if his participation will provide the court with information relevant to the choice of a remedy that will not be presented by an existing party to the litigation $^{46}$ or if he is so situated that the court will require his cooperation to implement an effective decree.

After a finding of liability in institutional litigation, a court should notify persons who may be affected by the choice of a remedy of the court's intention to reform the defendant institution's practices or structures and should invite those persons to move to intervene. ${ }^{47}$ If the court then deter-

45. In keeping with the practice of the Rules to provide separately for joinder and intervention, the proposed amendment should be incorporated into current Rules 19 and 24 and should make the following changes:

1. Amend Rule 19(a) by inserting after the first sentence the following: "A person who may be affected by the implementation of a remedial decree, who is subject to service of process, and whose joinder will not deprive the court of jurisdiction over the subject matter of the action shall be joined as a party in the action after the determination of plaintiff's entitlement to relief and before the grant of a remedy if (i) his participation will provide the court with information relevant to the choice of a remedy that will not be presented by an existing party to the litigation or (ii) he is so situated that the court will require his cooperation to implement an effective decree."

2. Amend Rule 24(a) by inserting after the first sentence the following: "Upon timely application anyone who may be affected by the implementation of a remedial decree shall be permitted to intervene in an action after the determination of plaintiffs entitlement to relief and before the grant of a remedy when (i) the applicant's participation will provide the court with information relevant to the choice of a remedy that will not be presented by an existing party to the litigation or (ii) he is so situated that the court will require his cooperation to implement an effective decree."

The standards for joinder and intervention should be the same under the two rules because the policy considerations necessitating the participation of potentially affected persons in the remedial process apply with equal force regardless of the mechanism through which such persons are brought into the litigation. See supra pp. 1477-80. Current Rules 19(a)(2)(i) and 24(a)(2) are similarly intended to provide alternate methods through which interested persons meeting a single set of criteria may be made parties. Rule 24(a)(2) "provides that an applicant is entitled to intervene in an action when his position is comparable to that of a person under Rule $19(\mathrm{a})(2)(\mathrm{i}), \ldots$. unless his interest is already adequately represented in the action by existing parties." FED. R. CIV. P. 24 advisory committee note.

46. This requirement is similar to the requirement under current Rules 19 and 24 that the absent persons' interest be one that is not adequately represented by a party to the action. See Toney $\mathbf{v}$. White, 476 F.2d 203, 207 (5th Cir. 1973) (Rule 19 implicitly requires inadequate representation as condition of joinder); FED. R. CIV. P. 24 (explicitly requiring inadequate representation as condition of intervention). Accordingly, a court implementing this test may look for guidance to the standard that has developed under current Rules 19 and 24 . That standard has been briefly summarized as follows:

The most important factor in determining adequacy of representation is how the interest of the absentee compares with the interests of the present parties. If the interest of the absentee is not represented at all, or if all exisiting parties are adverse to him, then he is not adequately represented. If his interest is identical to that of one of the present parties, or if there is a party charged by law with representing his interest, then a compelling showing should be required to demonstrate why this representation is not adequate. Finally, if his interest is similar to, but not identical with, that of one of the parties, a discriminating judgment is required on the circumstances of the particular case, but he ordinarily should be allowed to intervene unless it is clear that the party will provide adequate representation for the absentee.

7A WRIGHT \& MILLER, FEDERAL PRACTICE AND PROCEDURE: CIVIL § 1909, at 524 (1972).

47. Such notice is analogous to the notice of litigation concerning the disposition of a fund required to be given to persons with an interest in that fund. See Mullane v. Central Hanover Bank \& 
mines that a group of persons should be allowed to intervene and that the group constitutes a class within the meaning of Rule 23, the court should make some members of the group parties and should certify the group as a class and those members as its representatives. ${ }^{48}$ In so doing, the court should select representatives who have no interests relating to remedy formulation that conflict with those of other class members ${ }^{49}$ and should create subclasses if there are certain issues common only to some members of the class. ${ }^{50}$ Absent members of the class who have been given notice of the litigation may be expected to help ensure the adequacy of their representation by advising the court if they think the class representatives will fail to represent their interests adequately. ${ }^{51}$

The court should also attempt to identify those potentially affected persons who do not respond to its notice because they are pursuing a strategy of non-participation or because they are members of an inchoate group of which no member has sufficient incentive to step forward on the group's behalf. ${ }^{52}$ The court should then initiate proceedings to determine if those persons satisfy the criteria for remedial joinder. ${ }^{53}$

Joinder will often induce persons who are reluctant to become involved to play an active role in the remedial process and to abide by the decree that is implemented because it will foreclose all other means through which they may protect their interests. Res judicata and collateral estoppel

Trust Co., 339 U.S. 306, 319 (1950) (notice of litigation concerning fund in which there are large numbers of small interests "is likely to safeguard the interests of all, since any objections sustained would inure to the benefit of all"). Notice may often be disseminated through the institution's normal mechanisms for communicating with affected groups. In the case of an institution that operates in a single geographic location, such notice may be supplemented by publication. 28.

48. This procedure should conform to current practice under Rules 19, 23, and 24. See supra note

49. A class may be certified only if "the representative parties will fairly and adequately protect the interests of the class." FED. R. CIV. P. 23(a)(4). This requirement has often been interpreted to mean that the class representatives should have no relevant interests that conflict with those of the class. See Guarantee Ins. Agency v. Mid-Continental Realty, 57 F.R.D. 555, 565 (N.D. Ill. 1972); Thomas v. Clarke, 54 F.R.D. 245, 251 (D. Minn. 1971).

50. See FED. R. GIV. P. 23(c)(4)(B); Note, Defendant Class Actions, 91 HaRv. L. ReV. 630, 664 (1978) (discussing use of subclassing technique with respect to defendant classes).

51. Cf. Note, supra note 50, at 645 (once given notice, absent persons can appraise more accurately than court the likelihood that their proposed representative will be adequate).

52. Such persons will usually not intervene. See supra pp. 1481-82. The parties will also usually fail to initiate proceedings to join such persons because those persons' interests are adverse to the parties. See supra note 16 (remedial interests of plaintiffs and defendants are adverse to those of nonparties who may bear part of remedial burden). Nevertheless, a court will ordinarily encounter little difficulty identifying those absentees. See supra note 41 (discussing court's ability to identify such persons).

53. Both trial and appellate courts have the power under current Rule 19 to raise on their own initiative the issue of the joinder of a necessary or indispensable party. Provident Tradesmens Bank \& Trust Co. v. Patterson, 390 U.S. 102, 111 (1968); GTE Sylvania, Inc. v. Consumer Prod. Safety Comm'n, 598 F.2d 790, 798 (3d Cir. 1979), affd, 447 U.S. 102 (1980). This is a power, however, that the courts have rarely exercised. 
will prevent them from bringing a collateral judicial proceeding. ${ }^{54}$ And should the joined parties attempt through extrajudicial means to protect their interests, they will be subject to a variety of court ordered sanctions and supplemental orders. 55

It is proper to use joinder, sanctions, and the consequences of res judicata and collateral estoppel to induce the participation of reluctant parties who have interests that should be represented in remedy formulation. The draftsmen of the current rules recognized that necessary joinder would fail to protect the interests of the courts and the original parties if only persons who agreed to be joined could be made parties. ${ }^{56}$ Accordingly, current practice under Rule 19 often requires the joinder of persons who oppose their joinder and who, like those affected by the choice of a remedy, are free of liability for the plaintiff's injury. ${ }^{57}$ Although potentially affected persons will often benefit from their participation as parties, the primary purpose for their joinder is to protect the ability of the courts to fashion effective and final decrees. ${ }^{58}$ For this reason, they should be joined regardless of their wishes.

If an absent person chooses not to represent himself after joinder ${ }^{59}$ or cannot be joined, ${ }^{60}$ the court should formulate a remedy without his par-

54. See supra note 19 (affected persons are precluded from asserting their interests in collateral proceeding only if they are made parties to litigation).

55. Sce supra pp. 1478-79 (discussing limitations on court-imposed sanctions against persons who violate decrec).

56. The draftsmen therefore provided in Rules 19(a)(1) and 19(a)(2)(ii) for the joinder of persons in instances where joinder is in the interest of the court and the original parties, but not in the interest of the joined persons.

57. See, e.g., United States v. Wyoming Nat'l Bank, 505 F.2d 1064, 1066 (10th Cir. 1974) (creditor joined to suit adjudicating other creditor's rights to debtor's assets despite his desire not to participate); New York State Ass'n for Retarded Children, Inc. v. Carey, 438 F. Supp. 440, 443 (E.D.N.Y. 1977) (union that had expressly rejected invitation to intervene joined as necessary party in suit that might affect union members' rights); Arcy v. Goodyear Tire \& Rubber Co., 11 F.R.D. 209, 209 (N.D. Ohio 1951) (exclusive licensee of patent who refused to join as plaintiff in patent infringement action joined as necessary party).

58. See supra pp. 1477-80 (absence of potentially affected persons impairs ability of court to fashion and implement effective and final decree).

59. An American court lacks any tools stronger than the threat of a default judgment with which to coerce the participation of a reluctant party. See Millar, The Formative Principles of Civil Procedure, 18 ILL. L. REV. 1, 5 (1923). Cases will undoubtedly arise in which the threat of default is not sufficient to induce an affected person or group to participate in the litigation.

60. A court cannot make a person a party if his participation would destroy the court's jurisdiction over the subject matter of the litigation or, in the case of joinder under Rule 19, if he is not amenable to service of process. See FED. R. CIV. P. 19 advisory committee note. After a finding that a necessary party cannot be joined, a court ordinarily proceeds to "determine whether in equity and good conscience the action should proceed among the parties before it, or should be dismissed, the absent person being thus regarded as indispensable." FED. R. CIV. P. 19(b). The issue of the joinder of necessary remedial parties is properly raised, however, only after a finding of liability in the action. After such a finding, a court is under a duty to render a decree that will remedy the injuries of the plaintiff class. Green v. County School Bd., 391 U.S. 430, 438 n.4 (1968). For this reason, equity and good conscience can never compel the dismissal of a suit because a necessary remedial party cannot be joined. 
ticipation. In so doing, the court should employ the techniques available to it to elicit, albeit imperfectly, his knowledge and concerns. ${ }^{61}$ When possible, a court should also limit the scope of its decree to avoid its adverse effects on persons who cannot be joined. ${ }^{62}$

\section{The Remedial Parties Procedure Applied: An Illustration}

Valley v. Rapides Parish School Board ${ }^{63}$ is one of many lawsuits that have attempted to integrate a racially segregated public school system. ${ }^{64}$ The Valley litigation was commenced in $1965^{65}$ and, after five years of litigation, resulted in a determination that plaintiffs were entititled to a remedy creating a unitary integrated school system. ${ }^{66}$ The district court then entered a remedial order in which all parties to the litigation had acquiesced. ${ }^{67}$ That order dealt primarily with pupil and teacher assignments. In August, 1980, recognizing that its earlier decree had failed to integrate the schools in Alexandria, a city within Rapides Parish, the district court adopted a new remedial plan that, like its predecessor, dealt primarily with pupil and teacher assignments. ${ }^{68}$

61. See supra p. $1484 \&$ n.42. Such techniques, though less than fully effective, do provide a court with some information useful in the formulation of a remedy.

62. It will often be impossible so to limit a decree. The practices of an institution cannot ordinarily be modified for the benefit of one group without affecting the institution's practices with respect to other groups.

Thus, the desegregation of schools frequently requires radical changes for white pupils, teachers, and administrators. Jobs that are allocated to members of a group which has been the victim of discrimination are necessarily denied to other groups. Funds that must be spent to improve conditions in prisons or mental hospitals may be appropriated at the expense of other legislative programs. A court-ordered housing project may depress property values in its vicinity.

Special Project, supra note 15, at 906-07.

63. 499 F. Supp. 490 (W.D. La. 1980), rev'd in part, 646 F.2d 925 (5th Cir.), modified, 653 F.2d

941 (5th Cir. 1981), cert. denied, 102 S. Ct. 1430 (1982).

64. See supra note 4.

65. See Valley v. Rapides Parish School Bd., 646 F.2d 925, 929 (5th Gir.), modified, 653 F.2d 941 (5th Cir. 1981), cert. denied, 102 S. Ct. 1430 (1982).

66. In response to the decision in Green v. County School Bd., 391 U.S. 430 (1968), in which the Supreme Court held that freedom of choice plans are an ineffective means of remedying school segregation, the court of appeals held in Valley v. Rapides Parish School Bd., 422 F.2d 814 (5th Cir. 1970) (per curiam), that "effective immediately . . . school districts . . . may no longer operate a dual system based on race or color, ... they must begin immediately to operate as unitary school systems within which no person is to be effectively excluded from any school because of race or color." Id. at 815.

67. See Valley v. Rapides Parish School Bd., 499 F. Supp. 490, 490 (W.D. La. 1980) (original decree entered July 9, 1971), rev'd in part, 646 F.2d 925 (5th Cir.), modified, 653 F.2d 941 (5th Cir. 1981), cert. denied, 102 S. Ct. 1430 (1982). Three earlier decrees had been rejected by the court of appeals. Valley v. Rapides Parish School Bd., 434 F.2d 144 (5th Cir. 1970) (remedial plan relied on neighborhood concept that failed to integrate schools in Alexandria, a city in Rapides Parish); Valley v. Rapides Parish School Bd., 423 F.2d 1132 (5th Cir. 1970) (per curiam) (remedial plan that failed to integrate 12 substantially all black schools obviously deficient); Valley v. Rapides Parish School Bd., 422 F.2d 814 (5th Cir. 1970) (per curiam) (same).

68. See Valley v. Rapides Parish School Bd., 499 F. Supp. 490, 492-96 (W.D. La. 1980), rev'd on other grounds, 646 F.2d 925 (5th Cir.), modified, 653 F.2d 941 (5th Cir. 1981), cert. denied, 102 
In keeping with traditional practice, the only parties to the formulation of each of the remedial decrees were the United States, the private plaintiffs, and the defendant school board. ${ }^{69}$ Under the system of remedial joinder and intervention proposed in this Note, white families and the district's teachers would also have been represented in the litigation.

White families are affected by the choice of a remedy in a variety of ways. ${ }^{70}$ The children may be assigned to schools with facilities inferior to those of the schools they formerly attended. ${ }^{11}$ Their school days may be extended by lengthy bus rides. ${ }^{72}$ In addition, unless adequate provision is made for security within the schools, they may be exposed to racially motivated violence. ${ }^{73}$ White children and parents affected in these ways satisfy each of the criteria for joinder or intervention. They are situated such that they may be able to frustrate the court's decree. A child's enrollment in a particular school will be determined jointly by court order and parental decisions to maintain or change the family's residence and to enroll the child in a public or private school. ${ }^{74} \mathrm{~A}$ remedial decree can therefore be effective only if it anticipates parental decisions and obtains parental cooperation. ${ }^{75}$ White parents are also able to contribute to the formulation of an effective remedy by proposing ways in which a decree can minimize white flight from the schools. By accomodating issues of concern to white parents, such as the improvement or replacement of formerly black schools, ${ }^{76}$ the court would be able to reduce white parents' incentive to

S. Ct. 1430 (1982). The court had previously made certain minor adjustments to the 1971 plan on motion of the United States. See Valley v. Rapides Parish School Bd., 646 F.2d 925, 930, modified, 653 F.2d 941 (5th Cir. 1981), cert. denied, 102 S. Ct. 1430 (1982).

69. See Valley v. Rapides Parish School Bd., 499 F. Supp. 490, 490-91 (W.D. La. 1980), rev'd in part, 646 F.2d 925, modified, 653 F.2d 941 (5th Cir. 1981), cert. denied, 102 S. Ct. 1430 (1982).

70. Black families are of course similarly affected. Unlike white families, however, they have always been represented in school desegregation litigation. In instances where the named plaintiffs are unable to represent the interests of all black schoolchildren, courts already have the power under FED. R. CIV. P. 23 to create plaintiff subclasses.

71. See Bell, Serving Two Masters: Integration Ideals and Client Interests in School Desegregation Litigation, 85 YALE L.J. 470, 482-87 (1976) (discussing attempts in Boston, Detroit and Atlanta school desegregation cases to improve formerly black schools).

72. The distances the court could have ordered students bused in Rapides Parish were considerable. The modified decree actually implemented in 1980 called for the busing of certain students 15 to 20 miles. Battle of the Buckeye Three, TIME, Jan. 19, 1981, at 49; see Swann v. Charlotte-Mecklenburg Bd. of Educ., 402 U.S. 1, 30-31 (1971) (objection to busing may be valid when "time or distance of travel is so great as to either risk the, health of the children or significantly impinge on the educational process").

73. Although the risk of violence in school integration should not be overemphasized, a court ordering school desegregation must be prepared for its outbreak. Cf. R. CRAIN, THE POLITICS OF SCHOOL DESEGREGATION 292-304 (1967) (discussing violence attending desegregation of New Orleans public schools).

74. Coleman, supra note 21 , at 13 .

75. Id.

76. These issues apparently were neither raised by any of the litigants nor confronted by the court in the Valley litigation, see Valley v. Rapides Parish School Bd., 499 F. Supp. 490 (W.D. La. 1980), rev'd in part, 646 F.2d 925 (5th Cir.), modified, 653 F.2d 941 (5th Cir. 1981), cert. denied, 102 S. Ct. 
withdraw their children from those schools.

The Valley litigation also sought to affect the hiring and assignment of principals, teachers, teacher-aides, and other staff who work directly with children. ${ }^{\text {"7 }}$ Reassignment disrupts a faculty's settled expectations. It may also radically alter the nature of the jobs teachers and other staff members are expected to perform. The court may limit the discretion normally enjoyed by teachers and school administrators and may assign teachers accustomed to working with upper-middle class children to schools predominantly populated by black children from poor backgrounds. Those teachers may lack the training and skills to meet the educational needs of their new students. ${ }^{78}$ Frustrated by reassignment, they may also lack the desire to meet those needs. School faculty are therefore able to impair the educational benefits that integration is thought to provide black and white students. Teachers' unwillingness or inability to educate a pluralistic student body may also accelerate white flight from the schools. If allowed to participate in the formulation of a remedy, teachers may propose ways in which a decree may avoid problems the parties choose not to address. They may propose a decree that minimizes the disruption of their expectations and that assigns faculty members to those schools in which their talents may be put to best use. They may also convince the court of the need to provide additional training to enable teachers to perform their new functions. And, recognizing the educational needs of the various populations of school children in the district, they may be able to propose a system of student assignments that will achieve integration and that will enable the schools to respond effectively to students' needs.

The failure to make such persons parties to remedy formulation may have impaired the court's ability to integrate the Rapides Parish schools. The court gave little attention to white flight ${ }^{79}$ or the possibility of radical

1430 (1982); Valley v. Rapides Parish School Bd., 434 F.2d 144 (5th Cir. 1970), perhaps because the school board wished to preserve its discretion and authority, and plaintiff' counsel wished to promote busing as the primary school desegregation remedy. Cf. Special Project, supra note 15, at 885-86 (plaintiffs' counsel in school desegregation cases typically give less concern to relief designed to enhance educational opportunities of black children than to busing remedies).

77. The remedial decrees did in fact affect those practices. See Valley v. Rapides Parish School Bd., 653 F.2d 941, 942 (5th Cir. 1981) (remanding for clarification of district court's 1970 order governing faculty hiring and assignment as incorporated in the district court's 1980 order), cert. denied, 102 S. Ct. 1430 (1982); Valley v. Rapides Parish School Bd., 313 F. Supp. 1193, 1195 (W.D. La. 1970) (ordering that "ratio of Negro to white teachers in each school and the ratio of other staff in each, [be] substantially the same as each ratio is to the teachers and other staff, respectively, in the entire system"), rev'd in part on other grounds, 434 F.2d 144 (5th Cir. 1970).

78. See Bell, Book Review, 92 HARV. L. REV. 1826, 1829-31 (1979) (teachers in Portland, Oregon, public school system rendered school integration painful and scarring experience for black students due to their inability to cope with those students' needs).

79. The court approved attendance patterns for elementary school children with a view toward minimizing white flight, Valley v. Rapides Parish School Bd., 499 F. Supp. 490, 494 (W.D. La. 1980), rev'd on other grounds, 646 F.2d 925 (5th Cir.), modified, 653 F.2d 941 (5th Cir. 1981), cert. denied, 102 S. Ct. 1430 (1982), and successfully integrated the parish's elementary schools. See Valley 
remedial alternatives such as the closing or improvement of racially identifiable schools or the retraining of school faculties. ${ }^{80}$ As a result, the Parish's schools were somewhat less integrated after implementation of the court's 1980 plan than the court had anticipated. ${ }^{81}$ Indeed, of the 107 white seventh and eighth grade students reassigned from a suburban, allwhite school to the urban, racially mixed Jones Street School, only 22 actually enrolled. ${ }^{82}$ The court's decree also failed to bind the white students, giving rise to a highly publicized attempt by three families to transfer custody of their daughters under order of a state court to persons living in an area of the district in which children attended an all-white school..$^{83}$ The federal court was ultimately able to compel those students' attendance at the integrated school to which they had been assigned, ${ }^{84}$ but not without the expenditure of extensive judicial energy ${ }^{85}$ and the creation of substantial public sentiment opposed to the implementation of reform. ${ }^{86}$ The court could have employed its time and energy more effectively had it joined the white parents and children and the school faculty prior to the formulation of a remedy, at which time their participation could have resulted in the choice of a desegregation plan calculated to achieve integration in fact.

v. Rapides Parish School Bd., 646 F.2d 925, 932 n.3 (5th Cir.) (1980-81 enrollment figures for the affected elementary schools substantially identical to the court's projected enrollment figures), modified, 653 F.2d 941 (5th Cir. 1981), cert. denied, 102 S. Ct. 1430 (1982). The court gave less attention to white flight from junior high schools and integrated those schools less successfully. See id. at 933 (attainment of projected enrollment figures for affected junior high schools "somewhat frustrated by "white flight" ").

80. The court did close some predominantly white schools but dismissed in passing and apparently without serious consideration the possibility of closing the predominantly black Jones Street School. See Valley v. Rapides Parish School Bd., 499 F. Supp. 490, 494 (W.D. La. 1980), rev'd in part, 646 F.2d 925 (5th Cir.), modified, 653 F.2d 941 (5th Cir. 1981), cert. denied, 102 S. Ct. 1430 (1982). The court did not address the possibility of improving school facilities or retraining school faculty. Id.

81. See Valley v. Rapides Parish School Bd., 646 F.2d 925, 932-33, nn.3-5 (5th Cir.) (comparing projected and actual enrollment figures), modified, 653 F.2d 941 (5th Cir. 1981), cert. denjed, 102 S. C. 1430 (1982).

82. Battle of the Buckeye Three, TIME, Jan. 19, 1981, at 49.

83. Sec id.

84. In order to force the girls to attend their assigned school, the district court had to exercise its authority over a state court judge and local school officials. See Valley v. Rapides Parish School Bd., 646 F.2d 925, 936 (5th Cir.), modified, 653 F.2d 941 (5th Cir. 1981), cert. denied, 102 S. Ct. 1430 (1982); see also supra note 23 (describing efforts of district court to force girls to attend assigned school).

85. The legal skirmishing over the fate of the three girls consumed an extensive portion of the calendars of the federal district judge and the state court judge during the months of November, 1980 through January, 1981. See id. at 934-36 (describing extensive state and federal proceedings).

86. See N.Y. Times, Jan. 15, 1981, at A19, col. 1 (Ku Klux Klan and community group staged demonstrations); cf. Battle of the Buckeye Three, TiME, Jan. 19, 1981, at 49 ("For many local residents, the case has ... provided a chance to vent frustrations over their inability to control the schools as they see fit.") 


\section{Conclusion}

The provisions for necessary joinder and intervention were amended in 1966 to meet the changing needs of the judicial system. The emergence of institutional reform litigation has created the need for yet another amendment of the Rules. By requiring the participation in remedy formulation of persons who may be affected by the choice of a remedy, the courts will be able to fashion more effective and more final remedial decrees. 